\title{
Hollywood Works: How Creativity Became Labor in the Studio System
}

\author{
RONNY REGEV
}

Using the career of director William Wyler as a case study, the article argues that by standardizing creative professions such as acting and directing during the 1920s and 1930s, the Hollywood studio system was responsible for turning creativity into a modern form of labor. I make this claim by highlighting three main themes. First, the article draws attention to the operation behind cultural industries, as opposed to the content they produce, a topic that remains understudied. Second, it traces the historical development of "directing" as a profession. Looking at how this pivotal role changed since the early days of the industry, I argue there was a structural rationale behind practices of managerial control as well as those enabling creative autonomy. Third, focusing on Wyler's career, the article fleshes out how this dual rationale functioned day to day and how it pushed creative employees like Wyler to develop a particular professional way of being.

Historians have paid much attention to the ways in which culture became an industry and very little attention to how producers of culture became workers. ${ }^{1}$ This is despite the fact that, at least during the

() The Author 2016. Published by Cambridge University Press on behalf of the Business History Conference.

doi:10.1017/eso.2015.89

Published online January 7, 2016

Ronny Regev is a Lecturer in the Department of History at Princeton University. She is currently working on her first book, a labor history of the Hollywood Film Industry. Contact information: 129 Dickinson Hall, Princeton University, Princeton, NJ 08544. E-mail: rregev@princeton.edu

I would like to thank Daniel T. Rodgers, Paul DiMaggio, T. J. Jackson Lears, Anson Rabinbach, and Emily Thompson for their much needed advice as well as Nimisha Barton, Caley Horan, Andrei Pesic, and three anonymous referees for their careful reading and thoughtful comments. Research for this article was supported by the Center for Arts and Cultural Policy Studies at Princeton University.

1. There is indeed very little historical scholarship on work culture in creative industries. The few existing studies include Holmes, Weavers of Dreams, Unite!; Vanderlan, Intellectuals Incorporated; Davis, The Circus Age; Cook, The Arts of Deception; Denning, The Cultural Front; Hamilton, When I'm Bad, I'm 
twentieth century, creative industries developed distinct and influential labor systems. The American motion picture industry is a case in point. Hollywood filmmakers, be they actors, directors, or writers, are rarely thought of as employees. Still, actress Joan Crawford once claimed, "It is very important to put in the story that we have jobs the same as any girl in a ten cent store, and we do what we're told."2 Her fellow actor James Cagney concurred, explaining he was "just like a shipping clerk ... just a salaried employee.” He added, "This was part of the times, for everyone. This didn't apply only to [him]; it applied to everybody under contract."3 While screen luminaries like Crawford and Cagney are anything but obscure, their histories, as these quotes suggest, suffer from myopia. As media scholar Sean P. Holmes argued, an important part of these people's stories, namely their identity as workers, is repeatedly disregarded, hidden behind a "discourse of popular entertainment that divert[s] public attention away from the sphere of production." 4

Unlike historians, film scholars recognized long ago that American cinema was "the product of human labor." ${ }^{5}$ In his seminal book, The Genius of the System, Thomas Schatz familiarized the idea that "the quality and artistry of all [Hollywood] films" resulted from a "melding of institutional forces." Looking into the studio system's "relations of power and hierarchy of authority," Schatz and a series of other scholars concluded that, within big studios such as Warner Bros., MGM, and Universal, a "delicate balance" was struck that produced not only a "uniform style," but also a "consistent system of production" and a "set of formalized creative practices and constraints."6 Building on this rich body of literature, which seeks to uncover the mechanisms behind the film production process and shed light on the complex

Better; House, "Work House Blues"; Rose and Salzmann, "Bionic Ballplayers." The latter, admittedly, represents a larger body of literature that deals with the work of professional athletes.

2. Crawford to Katherine Albert, November 14, 1941, file 3.f-123, Gladys Hall Papers, Special Collections, The Margaret Herrick Library, Beverly Hills.

3. Reminiscences of James Cagney, December 1958, transcript, Popular Arts Project in the Oral History Collection, Columbia University, New York, 45.

4. Holmes, "The Hollywood Star System and the Regulation of Actors' Labour, 1916-1934,” 111.

5. See Nielsen, "Towards a Workers' History of the U.S. Film Industry."

6. See Schatz, The Genius of the System, 6-9; Bordwell, Staiger, and Thompson, The Classical Hollywood Cinema; Gomery, The Hollywood Studio System; Balio, The American Film Industry; Staiger, The Studio System; Schatz, Hollywood. Perhaps the most comprehensive study of the American motion picture industry is the impressive and invaluable series History of The American Cinema, a tenvolume series-written by various authors, including Balio, Lev, and Schatz-each of which covers a decade of filmmaking from the late nineteenth century to 1989 . See Harpole, History of the American Film. 
cooperative effort that stood behind this important cultural industry, I suggest there was an additional significant element to the system's genius-its distinctive labor force.

An influential cultural industry such as the one that developed around Hollywood between the 1920s and the late 1940s drew a great deal of its power from effective work relations, or what media scholar Janet Staiger calls its "sociology of production." As one of the most profitable industries in the United States as well as a quintessential American export, moviemaking relied, to a great extent, on its unique organization of the workforce, one that ensured both steady profits and creative innovation. In that sense, Hollywood's model of balancing artistic expression and a highly structured work routine served as a blueprint for the streamlining of creative production in all forms of media and entertainment. It outlined a professional way of being, one that would later come to be known, through the work of Richard Florida and others, as "the creative class."

Notwithstanding the industry's influential status, the existing literature still lacks, as Holmes put it, "any real sense of working in the Hollywood film industry as a lived experience."8 Even Staiger, whose own work on the Hollywood mode of production is invaluable, acknowledged recently that current scholarship only presents a "template to describe work behavior" and lacks a "theory of agency" that would explain "why individuals might pursue enacting those routines." 9 In other words, there is room for a labor history of Hollywood that takes into account the mundane practices of studio production as well as the particular forms of agency that developed in it, one that would explain the kind of professionals Crawford and Cagney had to be or become in order to enhance their value in the Hollywood labor market.

This article will demonstrate the day-to-day process by which the studio system turned creative practices into modern professions, using the workplace experience of legendary directory William Wyler as a case study. Famous for such classics as The Best Years of Our

7. See Florida, The Rise of the Creative Class; Pink, Free Agent Nation. Both authors suggest that the Hollywood labor market, especially the one that developed following the decline of the studio system in the 1950s provided the model for recent trends in the American labor market.

8. Holmes, Weavers of Dreams, 4. Holmes identifies and seeks to correct a similar problem in the literature concerning American theater.

9. Staiger made these claims in her introduction to a recent collection about authorship and film. See Gerstner and Staiger, Authorship and Film, 40-41; Bordwell, Staiger, and Thompson, The Classical Hollywood Cinema; Kemper, Hidden Talent; Clark, Negotiating Hollywood; Carringer, The Making of Citizen Kane; Jewell, "How Howard Hawks Brought 'Baby' Up”; Schwartz, The Hollywood Writers' Wars. 
Lives (1946), Roman Holiday (1953), and Ben-Hur (1959), Wyler is the subject of many popular biographies that chronicle his artistic achievements and glamorous Hollywood lifestyle. In all of these his worker identity is all but ignored and often even negated, while the authors confirm his standing as a "maverick who had the force of personality and artistic genius to withstand the dictatorial embrace of the most ruggedly self-aggrandizing moguls" that employed him. ${ }^{10}$ In short, a closer look at the years Wyler spent working for Universal, Warner Bros., and Samuel Goldwyn that examines the letters, interoffice communications, and production reports he left behind suggests the filmmaker's relationship with his bosses was more interesting. Wyler was a director and a worker. While he tried to test the boundaries of the studio's domination, he also heartily accepted and benefited from its patronage and resources. While the studios attempted to restrain him, they also made sure to provide enough creative and pecuniary autonomy to guarantee his conformity to the system. Both sides negotiated the balance of power in the workplace, and they did so more frequently than they argued about a line in the script.

The result was a liminal industrial position, one hanging between manager and employee, between independence and regulation, always both in and under control. In that sense, Wyler's work habits and environment were not unique; they reveal the "intricacies of film direction itself as a profession" and reflect a common daily reality, which, over time, came to define a whole field of commercial-creative expression. ${ }^{11}$ Focusing on Hollywood labor practices and work behavior strengthens our understanding of the historical connection between creativity and industrial labor. In addition, as I suggest toward the end of this article, this focus also helps sharpen theories of cinematic authorship by pinpointing the position of the director in the collaborative filmmaking process.

\section{The Function of a Director}

To understand how Wyler's personal story fits within the system as a whole, one has to begin with the changing role of the film director

10. Herman, A Talent for Trouble, 1; Madsen, William Wyler. This is despite the fact several recent filmmakers' biographies moved away from that binary to present far more complex and sophisticated accounts of their subject. See, for example, McBride, Frank Capra; McBride, Searching for John Ford; Eyman, Print the Legend; Callow, Orson Welles.

11. See Hutchings, "The Histogram and the List," 36. Hutchings promotes a structural approach to authorship that focuses on the intricacies of the profession as a whole as opposed to the "distinctiveness" of individual directors. 
in the Hollywood production process from the 1920s through the late 1940s. ${ }^{12}$ The function of a director was part of the motion picture industry almost since its inception. It became prevalent around 1907 when a separate worker was hired by companies to take over production. Staiger labels the years that followed as a "director system," to indicate that the common modus operandi was such that "one individual staged the action and another person photographed it," with the former responsible for "rewriting, directing, and editing" the product. The title "director" was probably borrowed from theater, where the same term was used for the person who "controlled the choices of scenery, costumes, and acting, and used a script as an 'outline' of the narrative."13 The demand for movies was high and constantly increasing; therefore, directors who could deliver pictures fast and consistently were hot commodities. As one of them put it in 1916, the director was "the mainspring of the new industry ... for he knew how to make bricks without straw."14

In those days, the producer and the director were the same person, and the terms were even used synonymously. ${ }^{15}$ Yet, a process of consolidation, reorganization, and rationalization that began in the mid-1910s transformed the American motion picture industry and the place of the director in it. By the early 1930s, as most scholars tend to agree, the film industry became a "mature oligopoly" — that is to say, a market structure that "institutes a mixture of rivalry and tacit cooperation with regards to pricing policies." 16 The merger movement concentrated control in the hands of five vertically integrated companies, namely Paramount, Loew's, 20th Century Fox, Warner Bros., and RKO, each of which held impressive production facilities, worldwide distribution networks, and strategically located theaters. These grand-scale operations were connected in a "symbiotic relationship" with two additional production-distribution companies, Universal and Columbia, and the distribution-only firm United Artists, all of which owned no theaters and are commonly referred to as the "little three." 17 Among all of them, they produced 60 percent of the

12. This chronological framework surrounds the "Golden Age" of Hollywood from the development of a rationalized production process and vertical integration in the early 1920s to the late 1940s or early 1950s when a series of events effectively transformed the nature of the industry, particularly the 1948 Supreme Court ruling in the Paramount Case, which effectively ordered all the big studios to divest.

13. Bordwell, Staiger, and Thompson, The Classical Hollywood Cinema, 117-123.

14. "Putting the Move in the Movies," The Saturday Evening Post, May 13, 1916.

15. See, for example, "To Picture Yosemite" or "St. George and the Dragon."

16. Kuenne, "Conflict Management and the Theory of Mature Oligopoly."

17. For a partial history of Universal, see Edmonds, Big U. A good background article on Columbia is Buscombe, "Notes on Columbia Pictures Corporation 1926-41." For an excellent historical study of United Artists, see Balio, United Artists. 
American industry's output, collected 95 percent of the national film rentals, and controlled 3,000 theaters. ${ }^{18}$

Clearly, this situation left very few options for employment outside the studio system. Luckily, the integrated nature of the industry ensured a steady cash flow from the box office back to the filmmaking facilities, allowing the production branch (i.e., the studio operations of the majors) to maintain a large roster of workers. At any given moment, a studio like Paramount had under its employment an army of producers, actors, writers, directors, editors, cinematographers, and any other kind of personnel. Their various departments were always fully staffed, and their members signed to contracts ranging from a few months to seven years. Even in the mid-1940s, when the system began to decline, the number of production workers employed by motion picture companies in Southern California stood at 21,775, out of which 804 were actors, 490 were screenwriters, and 160 were directors. ${ }^{19}$ Smaller studios and producers generally followed the stock company model, and the labor practices developed in it, albeit with some variation.

For directors, this organizational development had several implications. First, under the studio system, most became salaried employees, as profit-sharing contracts were not common phenomena before the late 1940s. ${ }^{20}$ Second, until the late 1930s, most directors were also under a long-term contract to one of the big studios. Freelancing or gaining the status of an independent producer-director was uncommon, a position generally reserved for a few star directors such as Cecil B. DeMill, Frank Lloyd, and Howard Hawks. ${ }^{21}$ The number of producer-directors increased dramatically after the formation of the Screen Directors Guild and its recognition by the studios in $1939 .{ }^{22}$ Finally, starting in the early 1920s, as Hollywood, in line with the rise of scientific management, came to be governed by "hierarchies of

18. Quotes and data from Balio, The American Film Industry, 253-255. The number of theaters relates to 1945, and it represents about $1 / 6$ of the total number of theaters in the United States. Despite this small percentage, the majors' 3,000 theaters were all "first-run houses." These theaters were usually located in big cities and exhibited new pictures. They could also charge higher ticket prices and therefore accounted for 70 percent of the nation's box office receipts. Of course, the majors invented the theater ranking system as a whole in order to protect their assets.

19. The data pertain to 1946 and are gathered from Bernstein, Hollywood at the Crossroads. Additional statistics can be found in Schatz, Boom and Bust, 333; Lev, Transforming the Screen, 1950-1959, 26; and Macgowan, Behind the Screen.

20. For more statistics about this, see Weinstein, "Profit-Sharing Contracts in Hollywood."

21. Rosten, Hollywood, 283.

22. For more about the rise of the producer-director as well as independent production, see Schatz, Boom and Bust, 80-83. 
salaried executives who rationalized operations to insure long term stability and profits," the director was no longer fully in charge. ${ }^{23} \mathrm{His}$ work was now part of a coordinated and well-regulated production apparatus. Even for freelancers, as film scholar Tino Balio explained, "the studio invariably retained rights of approval over the key ingredients of a production-namely, the underlying property, the script, the budget, and the stars-and, of course, over how the picture was to be marketed." 24 As director-turned-producer Thomas H. Ince explained in 1924, the director could no longer "get the germ idea of a plot, assemble a cast, go out on location and start to shoot, having only a hazy idea of what he was going to do."25

\section{The Function of Autonomy}

Production in the studio system was a disciplined procedure. Generally, filmmaking could be broken down into three stages: preparation, shooting, and assembly. For the most part, the first stage includes script preparation, budget outlining, and casting. During "shooting" the "images and sounds are inscribed on the film," and the final stage includes the editing together of the filmed material. ${ }^{26}$ One of the prominent features of the development of the American motion picture industry was the standardization of these stages, by further dividing them into well-defined tasks performed by specialists and supervised by a hierarchy of executives. In the preparation, or "pre-production" stage, scriptwriting, for example, was divided into story outline, continuity, title writing, dialog, and even gag writing. Work on the script was closely supervised by the head of the story department, the producer of the picture in question, and, most importantly, by the studio's head producer, who read all the drafts, ordered revisions, and authorized the final version. Similar supervision took place for all tasks in all stages of production. The only exception occurred during the actual shooting of the picture. When the cameras were rolling, executives took a step back and maintained a looser form of management, an anomaly whose rationale arose from the structural function of film directing.

Even within the standardization frenzy, directors-though under supervision-managed to maintain some of the original autonomy

23. Balio, Grand Design, 33.

24. Ibid., 81.

25. "Memoirs of Thomas H. Ince," Exhibitors Herald, December 20, 1924, 31. The standardization of production started already in the 1910s by people such as Ince, but it was only during the 1920s that this trend became dominant.

26. Terms are taken from Bordwell and Thompson, Film Art, 3-7. 
they held in the early days of the business. Especially in comparison to other creative professions such as writing, editing, and cinematography, directing was not subject to such an ignoble division of labor. Fredrick Winslow Taylor, the father of scientific management theory, observed that in any industry some professions require "rule-ofthumb" or "traditional knowledge and are therefore harder to break-up, supervise, and control." ${ }^{27}$ Studying work culture in the American iron industry, David Montgomery also noticed groups of craftsmen who "clearly directed their own work and that of their immediate helpers." He referred to this phenomenon as "the manager's brain under the workman's cap." ${ }^{28}$ Such a loose managerial structure is indeed common in creative industries, where studies show "there is a strong identification between the worker and both their 'means of production' and the product of their labour," thus rendering close supervision "marginal to the process of adding value." 29 In that sense, it might not be surprising that, between the late 1910s and the early 1930s, Hollywood developed a production routine that relied on the director's "rule of thumb," failing to break down the craft and leaving it almost completely in the hands of its practitioners. Still, the particular historical and structural circumstances that led to this condition are important.

As American cinema evolved into a modern business, keeping the director somewhat in control happened to be functional. There were several reasons for a studio to leave its director "alone on the floor." First of all, there were precedents. As mentioned, the notion of a film director was borrowed from the stage where, since the latter half of the nineteenth century, the director assumed the autonomous function of unifying the play's elements (i.e. story, acting, and scenery) into a coherent whole. ${ }^{30}$ In addition, the initial status of the profession, when directors assumed the producer's role as well as the creative power over their pictures, still echoed as this mode of production persisted with some variation in places like Germany and Russia throughout the 1920 s and 1930s. ${ }^{31}$ However, looking at the production routine of the large film companies in the United States from the early 1920s to the late 1940s, it appears that one of the main reasons for empowering the director was expedience.

Cooperation and supervision were the essence of efficient filmmaking, but they were harder to implement while the cameras

27. Taylor, The Principles of Scientific Management, 12-15.

28. Montgomery, The Fall of the House of Labor, 29.

29. Smith and McKinlay, "Creative Labour."

30. See Chinoy, "The Emergence of the Director."

31. For information about production practices in the early days of the medium, see Bowser, The Transformation of Cinema, 1907-1915; Brownlow, The Parade's Gone By; Jacobs, The Rise of the American Film. 
were rolling. Almost everything that had to do with moviemaking was expensive: cameras, sets, lighting, salaries-in particular those of stars-and raw film. If you were a major studio producing 40-70 films per year, then your expenses were very high, and you did what you could to contain them. One way to cut spending was to limit the usage of valuables-that is, of loaned or freelance actors and film. Preparing a detailed shooting script, scheduling multiple conferences about sets, and endless discussions about lighting and camera angles in the "pre-production" stage might have been conducive to creativity, but it also made sure that when Clark Gable or Greta Garbo came on set, they were not paid to idle around while the director and producer argued about a line in the dialog. Because of the stock company model, during the studio era, most star actors were under a long-term contract to one of the studios and, therefore, were not paid by the day. Still, there was a small but influential group of freelance character actors engaged on a film-by-film basis. In addition, the studios often loaned out their stars to one another. A delay in production forced the studio to extend its engagement with these short-term employees, thus paying them for the additional time. ${ }^{32}$ As one assistant director put it, "artistry, in this day and age, is not by any means a cheap commodity: it demands time, time is money, and production costs mount with amazing rapidity." 33

Another expensive commodity was film. Raw film, film stock, or the material from which one produces the negative of the picture was a whole technological field with its own innovations and competition. To begin, very few companies produced raw film, and those that did, including Eastman Kodak in the United States, Pathé and Dupont in France, and Agfa in Germany, often had preferential trading agreements in their countries. In addition, "printing," or the development of a negative into a "processed shot" that is eventually screened in theaters, was also a costly procedure ${ }^{34}$ Lack of planning or disagreement on the set could cause a waste of film as takes and scenes had to be shot multiple times to cover all available options and opinions until a consensus was reached.

As one might imagine, when a picture passed from preparation to the "shooting" stage, speed and determination were of the essence. Due to the high costs, the filming process was designed for efficiency, and as a result it was often chaotic. Players frequently came on set just for a few days, and the studio did not wish to call them back for

32. For the work of freelance actors see Holmes, Weavers of Dreams, 152-154.

33. Naumburg, We Make the Movies, 105.

34. For more on film stock technology, see Salt, Film Style and Technology. 
another paycheck. ${ }^{35}$ The time a company had on a particular stage or off-studio location was also expensive and therefore limited. As actress Myrna Loy described it, "You shoot all the scenes that happen to be on that set." Regardless of the plot sequence, she continued, "The set is what rules you." 36

For all these reasons, in the studio era the director, who was traditionally in charge of orchestrating filming, was now also required to work within cost-effective limitations. Unlike in the early days of the medium, on the studio stage a director had to know what he wanted and how to verbalize his wishes so that actors, cameramen, and other crew members would understand. He had to know how to shoot everything that was necessary without being superfluous. And he had to do all that was required of him quickly while keeping the final product coherent, appealing, and, if possible, profitable. ${ }^{37}$ Accomplishing these tasks required skill, and few possessed it. In the study he conducted of the industry, Leo C. Rosten found that in 1938 there were 244 active directors in Hollywood. That figure may seem considerable, but it pales in comparison to the 800 writers he counted and the 1,753 class A actors who were members of the Screen Actors Guild at the same time. ${ }^{38}$

The scarcity of such a skill set resulted in a unique work role within the film industry. To echo the words of Montgomery, the director was somewhere between a manager and a workman, a mixture of autonomous artist and employee. He worked under contract and supervision but was also the master of his own domain. He was counted upon to

35. Holmes points out that the practice of scheduling production around sets (filming all scenes that take place at the same set one after the other), as opposed to shooting according to the narrative structure of the picture (filming scenes following the sequence by which they appear in the script), was also influenced by the use of freelance actors and the studios' effort to keep the length of their employment to a minimum. See Holmes, Weavers of Dreams, 152-154.

36. Reminiscences of Myrna Loy, interview by Mr. and Mrs. Robert C. Franklin, June 1959, The Popular Arts Project in the Oral History Collection, 45.

37. Throughout the paper I use the masculine form in reference to directors. The reason is that, sadly, during the studio era there were virtually no women directors, or at least none that succeeded in sustaining a career within mainstream Hollywood. The situation was somewhat better in the early days of the industry when one could often come across a movie by Alice Guy Blaché, Margery Wilson, Ruth Ann Baldwyn, Grace Cunard, Cleo Madison, Ruth Stonehouse, Ida May Park, Elsie Jane Wilson, and Lois Weber. As the 1910s drew to a close, most of these women disappeared from the scenes. For more about their careers, see Mahar, Women Filmmakers in Early Hollywood; Hallett, Go West, Young Women!; Slide, The Silent Feminists; Slide, Early Women Directors; Smith, Women Who Make Movies.

38. Rosten, Hollywood, 283, 323, 333. Class A was a category of actors devised by the Screen Actors Guild, and it excluded extras as well as actors that did not receive screen credit. 
have an imaginative vision but also to realize it while working with, rather than against, the standardized production process. Failing to break up and divide the craft, studio bosses accorded the director the status of middle management, making him responsible for all the work and workers on set during the filming of a movie. ${ }^{39}$ Yet, they also expected him to behave like a dutiful employee at all other stages of production. In order to succeed in this work role, directors had to demonstrate a creative side as well as a conformist one, a balance that could only be maintained by understanding the circumstances of their industrial position. Successful directors understood the system. They managed to negotiate their place in it, as they knew how and when to play the reliable manager as well as how and when to play the conscientious employee.

\section{"Willy, I Would Be Grateful for Your Consideration"}

The career of William Wyler is a fine example of such workplace acumen. Learning the profession on the Universal lot, he spent his first ten years in Hollywood as an in-house director at this semi-integrated production-distribution company. In 1935, he started a long-term engagement with independent producer Samuel Goldwyn, which lasted until 1946. During the near decade he spent with Goldwyn, Wyler experienced more freedom, as his contract allowed him to take outside projects. The contract also allowed his boss to loan him out, and, together, these two features enabled the director to experience production operations at three of the major studios-Warner Bros., 20th Century Fox, and MGM. ${ }^{40}$ Following World War II, Wyler, along with directors Frank Capra and George Steven and producer Samuel Briskin, formed an independent production company called Liberty Films. The company, which did not fare well on its own, was sold to Paramount in 1948, and thus at the end of the studio era Wyler added another major to his resume. ${ }^{41}$ Independent producers and minor

39. The failure to break up the directing profession was not for lack of trying. During the 1920s, studios experimented with codirecting as well as the concept of a "dialog director," who would be responsible for orchestrating the actors as opposed to the camera work. These notions were eventually discarded. For accounts of such experiences, see Reminiscence of Irving Rapper, transcript, January 3, 1972, and Reminiscence of George Cukor, transcript, June 22, 1971. Both interviewed by Charles Higham for the Hollywood Film Industry Project.

40. Herman, A Talent for Trouble, 141.

41. Ibid., 296; Madsen, William Wyler, 288-289. Upon the sale of Liberty, Wyler received Paramount stock and signed a five-picture deal with the company, for which he was to produce each of these pictures on salary. 
studios did not operate exactly like the five majors, and naturally the five vertically integrated companies also had their differences. Still, as Staiger explained, commercial independent production "seems to have organized itself in similar fashion" as the other companies. Independent "work processes were that of a hierarchy with divided labor," and its "means of production were identical" to the big five and little three. ${ }^{42}$ Thus, Wyler's interactions with his various superiors present an excellent window through which to peek into the workplace experience of a Hollywood director.

Like many others in Hollywood, Wyler got his break from Carl Laemmle. The head of Universal was a relative (his mothers' cousin, to be exact) who, when Wyler was 18, offered him a job in his film company in New York. William, whose given name was actually Willi, was born in Alsace in 1902. He came to America in 1920 following uncle Carl's proposition, which was presented shortly after the two had met for the first time in Zurich. "I owe everything to him," Wyler commented, writing for Laemmle's funeral. " $[\mathrm{H}] \mathrm{e}$ brought me to this country ... and started me at $\$ 20$ a week" working in the mailroom, "from which he deducted $\$ 5$ in repayment of my passage ... he was both generous and shrewd." 43 As Universal had operations on both coasts, Wyler made his way to California, where he worked as a production assistant until he was given a chance to direct in 1925 . This opportunity arose when the director he was assisting, Arthur Rosson, received an offer from Paramount and walked out in the middle of production. The movie was a two-reeler titled Underworld, and Wyler asked his uncle to take over the production. His answer was yes, which made the new and youngest director on the Universal lot very excited. He wrote to thank Laemmle saying, "I feel surer of myself this time than in anything I have ever attempted ... because I frankly believe that I have the material within me to develop some day into one of your best commercial directors." 44

Though it is hard to talk about a typical career trajectory when it comes to film directors, Wyler's diverse experience, from two-reel westerns to prestigious high-budget features in several different studio settings, could be used to illustrate the professional practice as a whole, beginning with remuneration. In general, signing a studio contract ensured financial security. Put simply, studio directors made a lot of money. As Rosten's study uncovered, "the amount of money paid to movie directors is a potent testimonial to the importance which

42. Bordwell, Staiger, and Thompson, The Classical Hollywood Cinema, 317-319.

43. Eulogy for Carl Laemmle, n.d., file 50.f-658, William Wyler Papers, Special Collections, Margaret Herrick Library, Beverly Hills.

44. Wyler to Laemmle, July 3, 1925, file 50.f-658, William Wyler Papers. 
the motion picture industry attaches to their talents." ${ }_{45}$ As mentioned previously, most directors, though not all, were under contract to a studio, which engaged them for periods ranging from the production of a single film to seven years. In most cases, contracts included an "option" clause that enabled the studio, and only the studio, to cancel the contract at the end of every year. Wyler's first director's contract with Universal in 1927, for example, was for five years with a weekly salary of $\$ 250$ and a studio "option” every six months. However, each time Universal decided to "pick up" the option and keep him, Wyler's wage per week was to increase by $\$ 50 .{ }^{46}$ This was a modest income in movie-business terms, probably fitting for an unknown beginner. A confidential Universal memo from 1926 that lists the market value of "the most important directors," suggests that established professionals made between $\$ 1000$ and $\$ 2500$ weekly, with some like Allan Dwan and Henry King making $\$ 50,000$ per film. ${ }^{47}$

Gaining skill, experience, and success increased one's value. In 1931, after he had completed several non-Western feature films including Hell's Heroes (a very profitable "talkie” from 1929), Wyler's salary "leaped to seven hundred fifty dollars a week."48 Three years later, following the release of A House Divided (1931) and Counsellor at Law (1933), the director reported to his brother that he "finally signed a new contract with Universal," allowing for “\$1125.00 per week with forty-two week guarantee," and yearly options that "run as follows: \$1375; \$1550; \$1750; \$2250." If he was to be “laid off” for the remaining ten weeks, he had "the privilege of making one picture in Europe each year.” Wyler was pleased, writing, "I can feel very content and satisfied with this agreement. Very few companies are handing out yearly contracts these days and free lancing, that is, going from studio to studio for one or two pictures is only good for a few big directors." 49 Though still not one of Hollywood's top earners, Wyler had moved up. The fact that he was guaranteed employment for only 42 weeks was nothing out of the ordinary, nor was the fact that during his layoff period he was still under Universal's control. Signing a studio contract implied giving up one's independence; however, as Wyler indicated, at least until the late 1930s not many directors-or writers and actors, for that matter-were successful enough to afford the uncertain path of freelancing. Even Frank Capra, who was the

45. Rosten, Hollywood, 291.

46. Herman, A Talent for Trouble, 81.

47. Memorandum from Paul Kohner to Laemmle, November 8, 1926, reprinted in Koszarski, An Evening's Entertainment, 212-213.

48. Herman, A Talent for Trouble, 99.

49. Wyler to Robert Wyler, April 7, 1934, file 59.f-756, William Wyler Papers. 
most profitable director in the business during the 1930s, was committed to Columbia. ${ }^{50}$

How did one acquire the necessary skill to land a contract? Judging by Wyler's career, the answer seems to be a mixture of gift, audacity, and the ability to adapt to studio needs. A director was guaranteed employment if he could produce consistent box office success. But, of course, no one knew exactly how to do that. When a director had a track record, one could assess his chances of producing cost-effective pictures. In the case of a new director, however, all a studio had to work with was potential. Wyler had potential. After completing one of his first feature-length pictures, The Shakedown (1929), a series of inside-studio reviewers sent their favorable impressions, including one who wrote "excellent picture. Fine ending. Good suspense. Great Fight. Action and drama all the way. Think Willie Wyler deserves a good break after this one. Certainly seems to show high percentage of intelligence in his direction." 51

Laemmle thought so too, and he hoped he could mold this intelligence to Universal's benefit. In 1932, he wrote to Wyler saying, "You have demonstrated that you know how to make excellent pictures but, unfortunately we have not made money on them." Uncle Carl was not giving up; he was simply trying to enhance his nephew's business consciousness: "You are smart and observing enough to see that there is always a good future for a fine commercial director, while the day of the other kind is gone forever." The head executive was responding to the director's request to be assigned a new project titled Laughing Boy. Perhaps due to their familial ties, he tried the following manipulation: "If you can make [the picture] in such a way as to let us get by with even a small profit, I will be the happiest man in the world because it will not only justify my faith in you as a director but as a commercial success as well." ${ }^{52}$

Cultivating a new director was not an easy matter, and it proved especially difficult with Wyler. At some point producer Henry Henigson complained to Laemmle that "personally," he thought "the business of 'building directors' is an expensive method of procedure." If it was up to him, he wrote, "I would rather let the other fellow put them into school and then take them after they have had their schooling." 53

50. According to data gathered in 1938, Frank Capra was the highest paid director in Hollywood. His yearly income was $\$ 294,166$. Among the other 34 top earners were King, Cukor, Hathaway, Walsh, and Hawks. The latter was one of the few directors who were not under contract with a big studio. Wyler's name did not appear on the list. Information taken from Rosten, Hollywood, 292.

51. Studio report on The Shakedown, November 16, 1928, file 29.f-400, William Wyler Papers.

52. Laemmle to Wyler, August 2, 1932, file 50.f-658, William Wyler Papers.

53. Interoffice communication, Henry Henigson to Laemmle, December 12 , 1927, file 1.f-15, William Wyler Papers. 
However, if the process was fruitful, the studio was likely to find itself with exclusive rights to a top-grossing director who usually still had several years left in the draconian contract he signed when he was nobody—quite a valuable commodity, in other words. To achieve this result the company had to teach the director how to work for it, a process that often required exactly what Laemmle employed in his letter-patience and negotiation.

As mentioned, once the picture was released to the set, the director was in control; therefore, the main goal was to imprint the notion beforehand that it was worthwhile for him to be cost effective. $\mathrm{He}$ needed to understand that despite his creative autonomy while shooting, the studio still had the final word on both the movie and the career of its maker. Movie companies wanted their directors to understand that their autonomy, while respected, had clear limits. They wanted them to know certain things remained out of the director's hand, or as filmmaker George Cukor once put it, "there were certain things a fait accompli." 54

\section{Pre-Production}

The easiest place to assert studio authority was during the preproduction phase. While taking into consideration the director's will, studio heads carefully maintained their authority to decide which projects were to be made, by whom, and with how much. In April 1928, producer William Lloyd Wright informed Wyler, "I am handing you herewith the first four continuities [for] the Laemmle Novelties idea. Please read these carefully then come in and see me." These Novelties, conceived by the head of the company, were very particular in nature: "we will try to [do] a $\$ 750$ estimate on a four-day shooting schedule [and] we have only 700 feet top of negative that we can get into this product for they are one-reelers." Wright wanted the director to cooperate with the screenwriter, but he emphasized that "we must have any changes, which you and [the writer] may decide on ... on paper and an estimate taken before we go in production.” To drive the point home, the executive added, "[T]his is only business and in conformance with Mr. Laemmle['s] ... ideas of combining art with commercialism."55

Wyler was not excited about this assignment. He wrote back saying, "Although having much faith in the general idea of Laemmle Novelties ... I wish to register my opinion that the subjects as written are without cleverness ... being assigned to make these, I will naturally do my best, though regretting an honest lack of enthusiasm." 56

54. Reminiscence of George Cukor, 35.

55. Interoffice communication, William Lord Wright to Wyler, April 27, 1928, file 24.f-336, William Wyler Papers.

56. Interoffice communication, Wyler to Robert Walsh, May 15, 1928, William Wyler Papers. 
In studio terms, Wyler's words sounded like a threat or at least a challenge. To reaffirm the hierarchy, Wright shot back that same day: "I do not think it is up to you or me to decide what product the organization should make, but it is up to us to be good soldiers and go ahead and try to make as good product as we can, and with the common sense idea of conserving Mr. Laemmle's money." He instructed Wyler to keep on working on the Novelties and to leave "the policy of the class of material we are to make [to] be set by those who carry this responsibility and authority." 57 The young director's autonomy was not extended to story material.

Even ten years later, when he was already a well-known director, the chain of command was not much different. In 1938, Wyler already had several commercial successes behind him, including Dodsworth (1936), which he had made two years earlier. As a result, while no longer working for Laemmle, he had a more lenient contract that, the director himself recalled, included a clause "whereby I had the right to-after each film I did for Sam Goldwyn, I had the right to do one elsewhere." 58 Then he was "simply asked by Hal Wallis, who was in charge of [Warner Bros.] at the time" to direct Bette Davis in the story Jezebel. "The script was submitted to me, and it was already a finished script," said Wyler. He added, "If I hadn't liked the story I wouldn't have done it." 59 That was only because he was working out of contract. When, in 1940, Wyler refused one of Goldwyn's suggestions, the latter "in accordance with contract ... deemed [Wyler] suspended for a period of 16 weeks." 60 In almost all cases, the studio chose the story for the director. As a freelancer, the filmmaker had a right to say no. Under contract, even that liberty had a price. ${ }^{61}$

57. Interoffice communication, Wright to Wyler, May 15, 1928, William Wyler Papers.

58. Reminiscences of William Wyler, interview by Charles Higham, January 9, 1972, transcript, Hollywood Film Industry Project, 1.

59. Ibid., 14. Wyler's contract with Goldwyn, while including the right to accept outside projects, did not include a right of refusal for Goldwyn assignments. As Wyler noted in an interview in 1981, "when [Goldwyn] asked me to do one of these things, I refused and then I was what was called 'suspended and extended.' My contract was suspended for the length of time it took to make the picture [he was originally assigned].” See Wyler, William Wyler, 119.

60. Interoffice communication, Warner Bros. Studio, April 19, 1940, Copy, file 18.f-146, Rudy Behlmer Papers, Special Collections, Margaret Herrick Library.

61. Even when Wyler was working for Paramount, after selling his independent company Liberty Films to this major, he still needed to get approval for any project he sought to do from the studio's head producers. In 1949, he complained about this in a letter to his superior: "After your disapproval of both Look Homeward, Angel and Sister Carrie, I found myself in a position which I had hoped to avoid a year ago: once again I finish a picture to find that instead of being well along with preparations for my next one, I have to go back to the beginning and start looking for a new property." See Wyler to Henry Ginsberg, January 7, 1949, file 53.f-687, William Wyler Papers. 
Studio executives were not necessarily out to get their directors; they simply had broader concerns. While a director like Wyler was worried about his own career and the particular movie he was working on, people like Laemmle and Goldwyn were trying to coordinate a yearly program of features and a whole stock company of employees. When, in 1939, Jack Warner decided to "switch assignments" and have Anatole Litvak "do Twenty Thousand Years in Sing Sing ... with Raoul Walsh doing World Moves On," it was because the former was "getting nowhere" with his original assignment and not because of a particular grudge Warner held against the director. ${ }^{62}$ Furthermore, unless it conflicted with studio interests, in most cases head producers attempted to satisfy their directors. When, in 1944, Michael Curtiz told Warner he "would be truly grateful if you could assign me to something else until such time when God is My Co-Pilot is re-modeled into the script we all hope it eventually will be," his request was granted. ${ }^{63}$ Similarly, even back in 1931, if Wyler felt strongly against something, like directing a Tom Mix Western, Universal tried to reach an agreement with him. In this case, it was decided he would "direct and have the choice of stories available for the first Tom Mix picture," however, "at [his] opinion, [his] name will be left off the screen in this particular picture." In addition, Wyler was guaranteed "that the company will not ask [him] to direct any other picture of this series" and that he will "definitely [be] assigned to direct the new Lew Ayres picture." 64 It was a give and take relationship with the power scale tipped in favor of the studio.

\section{Shooting}

When pre-production ended, however, the balance was shifted. Head producers and executives were now at the mercy of the director. During production there was very little a producer could do to manage the way a picture was shot. The director was the manager in charge, and it was up to him to decide how much time to spend on rehearsals, what angles to shoot a scene from, and how many "takes" to shoot until he got the right one. To be sure, studio executives never left their filmmaker completely alone. They had spies in the form of production assistants, line producers, and scripts clerks. Over at Warner Bros., for example, head producer Wallis was kept in close touch with

62. Interoffice communication, Walter MacEwen to Hall Wallis, June 14, 1939, Hal Wallis Papers, Special Collections, Margaret Herrick Library.

63. Interoffice communication, Michael Curtiz to Jack L. Warner, February 25, 1944, Hal Wallis Papers.

64. Interoffice communication, Wyler to Henigson, February 3, 1928, file 57.f-736 William Wyler Papers. 
ongoing productions, even when he was on vacation. In 1942, while in Europe, he kept receiving daily reports such as this: "I have spoken to assistants and briefly to Hawks, Shumlin and Curtiz, and they all say everything is going along smoothly and well." 65 Sometimes the news was not so encouraging. In October 1941, an assistant to the production of King's Row sent the following memo:

Yesterday, Monday, this company was called for 9:00 AM shooting on Stage 14, had their first shot at 9:10 and finished shooting at 6:00 PM last night. This company shot 5 script scenes and finished Sc. 220 in 8 set-ups for a total of 0,25 ", over $2-1 / 4$ pages of dialogue... This will be 23 days over the schedule and very considerably over the budget. Considering the broken manner in which this show has been shot as regarding sets, cast, etc., I only hope it fits together right. I have never seen a picture shot in such a hurried manner as this picture had been made. ${ }^{66}$

Such reports were all too common and spelled out a very expensive delay. Yet, as we shall see, even in these cases executive producers could do little but plead, or sometimes even beg.

Wyler was a master of delay, mostly because he was infamous for shooting every take multiple times earning such nicknames as "once more Wyler." He saw it a bit differently. "It's true that in some cases" he shot scenes "too many times over and over." But, he claimed, "I do until I get it the way I want it ... there's always a purpose behind it and a reason for doing it over." ${ }^{67}$ The various studios he worked for quite obviously respected his creative sensibilities, as they kept hiring him or "picking up" his option. Yet, whether it was with Universal, Goldwyn, or Warner Bros., producers kept trying to rein him in. This audacious director revealed his penchant for extravagance very early on. Already in 1927, his uncle wrote to him observing, "You have only shot 73 scenes so far on your picture, spending $\$ 46,000.00$. Therefore you have only $\$ 45,000.00$ more to spend and still have 256 scenes to shoot." There was still hope for the young director, and so Laemmle emphasized, "Willie, don’t forget you are on trial now ... please, for your own sake more than for the company's sake, do your darndest to bring this picture in on estimate and still give us a good production." 68

65. Paul Nathan to Hal Wallis, June 24, 1942, file 229.f-2257, Hal Wallis Papers.

66. Interoffice communication, Frank Mattison to T. C. Wright, October 7, 1941, Copy, file 17.7-139, Rudy Behlmer Papers.

67. Reminiscences of William Wyler, 11.

68. Interoffice communication, Laemmle to Wyler, December 7, 1927, file 1.f-15, William Wyler Papers. 
Despite his "talent for trouble," companies kept hiring Wyler: his abilities were valuable even though he was a supposed "bad employee." This was not necessarily because his movies were profitable, because not all of them were. Something in Wyler's skillful filmmaking made him also a "good employee" and kept his relationship with major studios alive. That something was his studio conformity, his companyloyal "manager's brain." Whatever problems he caused during filming in the name of artistic integrity, underneath it all Wyler also internalized the economics of filmmaking. He understood that if a director takes too much time to shoot, "naturally ... the cost sheets show it," and in that case, as he said, "I hope the picture shows it, too." In fact, regardless of "how good it may be," as Wyler wrote to his brother in 1932, there was such a thing as taking "too much time." He observed that "costs are too high nowadays and our schedules are very short. The quality is expected to be of a high standard, but even at a sacrifice of quality pictures must be gotten out comparatively fast." ${ }^{69}$ Overall, he was a team player.

On the set he was still a renegade. Back in 1927, while shooting The Shakedown, production was behind once again. "Willie, I must impress upon you the necessity of making these pictures ... for sixty thousand dollars," his producer wrote. "If you cooperate with me on this picture," he pleaded, "I promise to do my utmost on the next picture you make, and obtain permission to give you a little more leeway."70 Such promises were rather useless, as Wyler was pretty comfortable making leeway for himself. As much as he internalized the economic necessities of the studio, the director was also keenly aware of his privileged position on the set. As mentioned, executives had very little control in this domain. As Darryl Zanuck, the head producer of 20th Century Fox was reported to have said, "On the set the director has 90 percent control. You may be able to persuade him to do this or that, but only within 10 percent. The rest of it, he's going to do it." 71 Armed with this structural understanding, Wyler knew where to assert his creative authority, a practice that on occasion elicited desperate pleas from the highest ranks. "I must ask you again to co-operate with us," Jack Warner wrote to him in 1940. "[Y]ou know we cannot spend the time on this picture ... Willy, I would be grateful for your consideration." 72

69. Wyler to Robert Wyler, January 5, 1932, file 59.f-755, William Wyler Papers.

70. Inter Office Communication, Henigson to Wyler, 3 Feb. 1928, file 29.f-400, William Wyler Papers.

71. Nunnally Johnson, interviewed by Thomas Stempel, 1968-1969, transcript, Louis B. Mayer Foundation of Oral History, 159-161.

72. Interoffice communication, Warner to Wyler, June 11, 1940, file 1.f-15, William Wyler Papers. 
One reason for this repeated series of entreaties was that, wasteful as a director could be, it was still more expensive to replace him. When a film changed directors everything almost always had to be done over. Take the case of The Wizard of Oz (1939). "Dick Thorpe started it," remembered producer Mervyn Leroy, but he "just didn't have the feeling of the [picture]." Then, George [Cukor] started it too, and George is a great director ... but he wasn't happy in what he was doing, so we got Victor Fleming." It was not really anybody's fault- "they were all honest." Nevertheless, "everything that George shot or Dick shot was not in the picture at all."73 Cukor himself experienced a similar problem in 1932 when he worked with Lubitsch on One Hour with You. He was asked to take over the direction duties until the latter finished another picture he was involved with. When the German master, whose reputation and experience placed him above the average director at Paramount, returned he discarded most of the work already done. The problem, as Cukor saw it, was that though he "directed quite a lot ... it didn't have the style of Lubitsch." Despite "the best intentions in the world," he explained, "I was not Lubitsch, and I could not shoot a Lubitsch picture."74 The making of a studio motion picture, it appears, required a coherent vision. In practical terms, then, once shooting started it might be cheaper to contend with an inefficient director than to replace him so late in the game.

\section{Post-Production}

All of these troubles ended as soon as the shooting process was over. As Capra mentioned in an op-ed from 1939, Hollywood filmmakers did not have the right to compose the "final cut" of their picture. ${ }^{75}$ Though they were often involved in the editing process, the decision about what takes to use and in what order-in other words, decisions about how the movie would actually look-belonged ultimately to the studio and its head producer. During post-production it was once again the director's turn to beg, and so it was with Wyler. ${ }^{76}$ "You have given instructions to have the "E" sequence cut without consulting me or giving me the benefit to see the sequence assembled and instructing the cutter," Wyler wrote to his producer in 1933. This correspondence came following the filming of Her First Mate and the director felt the "result is very unfortunate and the first half of "E"

73. Mervyn Leroy, “Reminisces of Mervyn Leroy," interviewed by Charles Higham, July 12, 1971, transcript, Hollywood Film Industry Project, 13.

74. Reminiscences of George Cukor, 4-5.

75. Frank Capra, “By Post from Mr. Capra,” New York Times, April 2, 1939.

76. One should note that experienced directors developed sophisticated ways to overcome their lack of control over editing. One such method, which Wyler was fond of, was to shoot long takes, which were harder to cut and interfere with. 
sequence ... is very disappointing and $\ldots$ almost unrecognizable, for it has lost its effectiveness." He wanted to "recut scenes in the manner [he] visualized," an operation he considered "an important part of [his] work." That said, he acknowledged, "I fully realize, that you [the producer] are in full jurisdiction over the production of this picture and would like to know how you stand in the manner."77

In the same way executives attempted to appeal to their directors' commercial sense, the latter seem to have phrased their pleas in creative terms. Later in 1933, Wyler was producing Counsellor at Law. While viewing the edited version of his footage, he noticed the deletion of one line-“tell him to go to hell"-from the last reel. He wrote to Laemmle Jr., Carl's son, who took over the studio in the late 1920s, "respectfully calling [his] attention to the fact that the deletion ... is extremely damaging to the picture." This was "not because of the humor of the particular line, but because with the deletion the climax of the picture remains unrelieved and we eliminate the only bit of comedy relief in the ending of the picture." The director believed that it was "absolutely necessary, in order to obtain the proper change of mood from any audience to [include this] piece of comedy relief."78 Since the line does not appear in the film, one could assume that with most executives the use of creative jargon had about the same effect as using commercial language to speed up directors-that is, little effect whatsoever.

\section{Primary Authorship}

Wyler inevitably lost some battles, especially in the pre- and post-production stages. But at other times, especially while on set, he got his way. Regardless, in any fight, at any stage, he understood his odds. Wyler knew the best time for a director to test the limits of studio control was during shooting, while before and after one had to be more cautious or face suspension. Even his attempt to disavow studio hierarchy and start his own company was in line with the commercial practices of the major studios, which, in the mid 1940s, started outsourcing projects, focusing more heavily on distribution, and relying on independent production companies. ${ }^{79}$ Wyler directed his labor practices according to the intricacies of his workplace and industry.

77. Interoffice communication, Wyler to Henigson, May 31, 1933, file 14.f-192, William Wyler Papers.

78. Interoffice communication, Wyler to Laemmle Jr., November 13, 1933, file 7.f-86, William Wyler Papers.

79. Beginning in the mid-1940s, a series of major economic disturbances hit the film industry. The most serious among these were, first, the rise of television as a market competitor; second, changes in the tax code that increased taxation on individual salaries but not on profits; third, and most significant, a Supreme Court 
In a sense, Wyler's career, as it reflects the work of many successful directors in the studio system also illuminates the role of the Hollywood director vis-à-vis the question of film authorship. As film scholar C. Paul Sellors recently pointed out, "authorship is a problem in film studies that simply will not go away." 80 The concept of the filmmaker as an auteur, introduced in the 1950s by French film critics André Bazin and François Truffaut, helped elevate cinema to the level of art by creating a causal connection between the motion picture and the worldview of an artist-creator. Placing emphasis on mise en scène, style, and thematic consistency, film critics could assert that some directors express an individual vision via their cinematic body of work. Yet, while the "auteur theory," as it has come to be known, turned into "common wisdom" in our understanding of popular culture, as Barry Keith Grant explains, its implied rigidity "opened the floodgates of critical scorn." ${ }^{11}$ One common charge is that by stressing the director-film connection, the theory fails to account for the collaborative nature of filmmaking and the contribution of other creative agents like writers, actors, cinematographers, or, regarding the studio system specifically, corporate decision makers. ${ }^{82}$

In an attempt to overcome this problem, several film scholars have recently advocated for a structural approach to the study of authorship. According to this model, as Peter Hutchings clarifies, film authorship does not necessarily entail "an act of personal artistic expression," which is "detectable by a critic," but is instead "concerned with the film maker's position within the industry, with status, control and influence." ${ }^{83}$ That is to say, the position of an auteur is derived here

decision in the 1948 Paramount Case that ordered all the major studios to divest thus ending vertical integration. As a result, the Hollywood mode of production changed dramatically. Major studios began to downsize. They replaced the stock company model and concentrated more and more on distribution and marketing while outsourcing film production to the growing sector of independent companies. For more on this process and its implications, see John Sedgwick, "Product Differentiation at the Movies."

80. Sellors, "Collective Authorship in Film," 263.

81. Grant, Auteurs and Authorship, 1-3. For an overview of the auteur theory and the debates concerning it, see Grant's book as well as Gerstner and Staiger, Authorship and Film; Wexman, Film and Authorship; and Caughie, Theories of Authorship. Grant and Gerstner suggest part of the reason auteurism became vulnerable to criticism was its transformation, by American film critic Andrew Sarris, from a way to analyze and critique films to an all-encompassing film theory, a status for which it lacked the necessary explanatory power.

82. The scholar most identified with this critique is Schatz, in The Genius of the System. See also Carringer, The Making of Citizen Kane. Other common debates include arguments over what constitutes an auteur as well as the poststructuralist approach that claims authorship is a "reading strategy" and sees the production of meaning as a subjective interpretive action performed by the audience.

83. See Hutchings, "The Histogram and the List," 34-35; Stollery, "Technicians of the Unknown Cinema”; Carringer, "Collaboration and Concepts of Authorship”; Collins, Radner, and Collins, Film Theory Goes to the Movies. 
not from film content, but from the institutional context of film production. The identity of a film author can only be deduced from a methodical understanding of how a film was made, an understanding that could reveal the creative agent who exerted the most control over the production process. Laying the groundwork for a "collaborative analysis” of film authorship, Robert L. Carringer suggests one has to begin any critical review by temporarily suspending any notion of "single author primacy" in order "to appraise constituent claims to a [film's] authorship." Only after assessing the conditions of production and the contribution of other agents can one identify the "primary author" of the picture. ${ }^{84}$

Indeed, enjoying a high level of autonomy as well as embracing an overall conformist, semimanagerial responsibility toward the fruit of their labors, directors developed a unique institutional relationship to the means of production within the Hollywood studio system. As Wyler's interaction with his superiors entails, if they adapted to industry norms, directors were accorded the primary position within the cinematic production process, the position from which they held the greatest amount of influence on any particular film. That is not to say all directors in the studio systems were auteurs. Rather, for those who understood how to harness their creativity to the apparatus, Hollywood offered a space for authorship. In other words, while reorganizing film production in the 1920s and redesigning it for efficiency, the studios also created structural conditions for film authorship. Skillful directors, such as Wyler, learned how to work within these conditions, thus developing workplace "practices of authorship." 85 They became system-made auteurs. In fact, the industrial positions of directors within the system and their influential status during the crucial shooting stage were in large part what enabled future critics to mark the director as the creative genius of cinema.

However unique they were, directors were not the only ones who developed a distinguished professional way of being in the American film industry. The structured work routine of the Hollywood studios cultivated a cohort of workers adept at functioning in this highly standardized environment of creative production. These workers, directors like Wyler but also actors such as Crawford and Cagney, screenwriters, cinematographers, editors, and so forth emerged as a new class: they were wage laborers with exorbitant salaries, artists subject to budgets and supervision, stars bound by contracts. They all developed ambivalent

84. See Carringer, "Collaboration and Concepts of Authorship,” 377-378.

85. Sellors, "Collective Authorship in Film," 263-264. Sellors claims authorship is never "a concept to be derived from a text," but rather "an intentional action of an intending agent that causes a text." 
workplace identities, suitable for an environment that demands artistic expression as well as efficiency. In their own way, they redefined the idea of "the artist" or "the auteur" in the twentieth century while also stretching the category of labor. Working in Hollywood, these people played a meaningful role in American labor history, one that should be studied alongside their contribution to the screen.

Bibliography of Works Cited

\section{Books}

Balio, Tino. United Artists: The Company Built by the Stars. Madison: University of Wisconsin Press, 1976.

- (ed.). The American Film Industry, rev. ed. Madison: University of Wisconsin Press, 1985.

—. Grand Design-Hollywood as a Modern Business Enterprise, 19301939, vol. 5, History of the American Cinema. New York: Scribner, 1993.

Bernstein, Irving. Hollywood at the Crossroads: An Economic Study of the Motion Picture Industry/Especially Prepared for the Hollywood A.F. of L. Film Council. Hollywood: Hollywood A.F.L. Film Council, 1957.

Bordwell, David, Janet Staiger, and Kristin Thompson. The Classical Hollywood Cinema: Film Style \& Mode of Production to 1960. New York: Columbia University Press, 1985.

Bordwell, David, and Kristin Thompson. Film Art: An Introduction. AddisonWesley Series in Speech, Drama, and Film. Reading, MA: Addison-Wesley Pub. Co, 1979.

Bowser, Eileen. The Transformation of Cinema, 1907-1915. Berkeley: University of California Press, 1994.

Brownlow, Kevin. The Parade's Gone By. 1st ed. New York: Knopf, 1968.

Callow, Simon. Orson Welles. 1st American ed. New York: Viking, 1996.

Carringer, Robert L. The Making of Citizen Kane. Rev. ed. Berkeley: University of California Press, 1996.

Caughie, John (ed.). Theories of Authorship: A Reader. London and Boston: Routledge \& Kegan Paul in association with the British Film Institute, 1981.

Clark, Danae. Negotiating Hollywood: The Cultural Politics of Actors' Labor. Minneapolis: University of Minnesota Press, 1995.

Collins, Jim, Hilary Radner, and Ava Collins (eds.). Film Theory Goes to the Movies. New York: Routledge, 1993.

Cook, James W. The Arts of Deception: Playing with Fraud in the Age of Barnum. Cambridge, MA: Harvard University Press, 2001.

Davis, Janet M. The Circus Age: Culture \& Society Under the American Big Top. Chapel Hill: University of North Carolina Press, 2002.

Denning, Michael. The Cultural Front: The Laboring of American Culture in the Twentieth Century. London: Verso, 1997.

Edmonds, I. G. Big U: Universal in the Silent Days. South Brunswick, NJ: A. S. Barnes, 1977. 
Eyman, Scott. Print the Legend: The Life and Times of John Ford. New York: Simon \& Schuster, 1999.

Florida, Richard L. The Rise of the Creative Class: And How It's Transforming Work, Leisure, Community and Everyday Life. New York: Basic Books, 2002.

Gerstner, David A., and Janet Staiger (eds.). Authorship and Film. New York: Routledge, 2003.

Gomery, Douglas. The Hollywood Studio System. New York: St. Martin's Press, 1986.

Grant, Barry Keith (ed.). Auteurs and Authorship: A Film Reader. Malden, MA, and Oxford: Blackwell Publishers, 2008.

Hallett, Hilary A. Go West, Young Women! The Rise of Early Hollywood. Berkeley: University of California Press, 2013.

Hamilton, Marybeth. When I'm Bad, I'm Better: Mae West, Sex, and American Entertainment. Berkeley: University of California Press, 1997.

Harpole, Charles (ed.). History of the American Cinema. 1st ed. New York: Charles Scribners \& Sons, 1990.

Herman, Jan. A Talent for Trouble: The Life of Hollywood's Most Acclaimed Director, William Wyler. New York: G.P. Putnam's Sons, 1995.

Holmes, Sean P. Weavers of Dreams, Unite! Actor's Unionism in Early TwentiethCentury America. Urbana: University of Illinois Press, 2013.

Jacobs, Lewis. The Rise of the American Film: A Critical History. New York: Harcourt, Brace and Company, 1939.

Kemper, Tom. Hidden Talent: The Emergence of Hollywood Agents. Berkeley: University of California Press, 2010.

Koszarski, Richard. An Evening's Entertainment: The Age of the Silent Feature Picture, 1915-1928. New York: Scribner, 1990.

Lev, Peter. Transforming the Screen, 1950-1959, vol. 7, History of the American Cinema. New York: Charles Scribner's Sons, 2003.

Macgowan, Kenneth. Behind the Screen: The History and Techniques of the Motion Picture. New York: Delacorte Press, 1965.

Madsen, Axel. William Wyler: The Authorized Biography. New York: Crowell, 1973.

Mahar, Karen Ward. Women Filmmakers in Early Hollywood. Baltimore: Johns Hopkins University Press, 2006.

McBride, Joseph. Frank Capra: The Catastrophe of Success. New York: Simon \& Schuster, 1992.

- Searching for John Ford: A Life. New York: St. Martin's Press, 2001.

Montgomery, David. The Fall of the House of Labor: The Workplace, the State, and American Labor Activism, 1865-1925. Cambridge, New York, and Paris: Cambridge University Press, 1987.

Naumburg, Nancy (ed.). We Make the Movies. New York: W. W. Norton \& Company, 1937.

Pink, Daniel H. Free Agent Nation: How America's New Independent Workers are Transforming the Way We Live. New York: Warner Books, 2001.

Rosten, Leo Calvin. Hollywood: The Movie Colony, the Movie Makers. New York: Harcourt, Brace and Company, 1941. 
Salt, Barry. Film Style and Technology: History and Analysis. London: Starword, 1983.

Schatz, Thomas. The Genius of the System: Hollywood Filmmaking in the Studio Era. 1st ed. New York: Pantheon Books, 1988.

- Boom and Bust: The American Cinema in the 1940s, vol. 6, History of the American Cinema. New York: Scribner, 1997.

- (ed.). Hollywood: Critical Concepts in Media and Cultural Studies. London: Routledge, 2003.

Schwartz, Nancy Lynn. The Hollywood Writers' Wars. 1st ed. New York: Knopf, 1982.

Sedgwick, John, and Michael Pokorny (eds.). An Economic History of Film. London, and New York: Routledge, 2005.

Slide, Anthony. Early Women Directors. South Brunswick, NJ: A. S. Barnes, 1977.

- The Silent Feminists: America's First Women Directors. Lanham, MD: Scarecrow Press, 1996.

Smith, Sharon. Women Who Make Movies. Cinema Studies Series. New York: Hopkinson and Blake, 1975.

Staiger, Janet (ed.). The Studio System. New Brunswick, NJ: Rutgers University Press, 1995

Taylor, Frederick Winslow. The Principles of Scientific Management. New York and London: Harper, 1911.

Kemper, Tom. Hidden Talent: The Emergence of Hollywood Agents. Berkeley: University of California Press, 2010.

Vanderlan, Robert. Intellectuals Incorporated: Politics, Art, and Ideas inside Henry Luce's Media Empire. Philadelphia: University of Pennsylvania Press, 2010.

Wexman, Virginia Wright (ed.). Film and Authorship. New Brunswick, NJ and London: Rutgers University Press, 2003.

Wyler, William. William Wyler: Interviews. Edited by Gabriel Miller. Jackson: University Press of Mississippi, 2010.

\section{Articles and Book Chapters}

Buscombe, Edward. "Notes on Columbia Pictures Corporation 1926-41." Screen 16, no. 3 (1975): 65-82.

Carringer, Robert L. "Collaboration and Concepts of Authorship." PMLA 116, no. 2 (2001): 370-379.

Chinoy, Helen Krich. "The Emergence of the Director." In Directors on Directing: A Source Book of the Modern Theater, rev. ed., edited by Toby Cole and Helen Krich Chinoy. Indianapolis: Bobbs-Merrill, 1963.

Holmes, Sean P. "The Hollywood Star System and the Regulation of Actors' Labour, 1916-1934." Film History 12, no. 1 (2000): 97-114. doi:10.2307/ 3815272.

House, Roger. "Work House Blues: Black Musicians in Chicago and the Labor of Culture during the Jazz Age." Labor 9, no. 1 (2012): 101-118. doi:10.1215/ 15476715-1461140.

Hutchings, Peter. "The Histogram and the List.” Journal of Popular British Cinema 4 (2001): 30-39. 
Jewell, Richard B. "How Howard Hawks Brought 'Baby' Up: An 'Apologia' for the Studio System." Journal of Popular Film and Television 11, no. 4 (1984).

Kuenne, Robert E. "Conflict Management and the Theory of Mature Oligopoly." Conflict Management and Peace Science 10, no. 1 (1988): 37-57.

Nielsen, Michael. "Towards a Workers' History of the U.S. Film Industry.” In The Critical Communications Review, edited by Vincent Mosco and Janet Wasko.. Norwood, NJ: Ablex Pub., 1983.

Rose, Sarah F., and Joshua A. T. Salzmann. "Bionic Ballplayers: Risk, Profit, and the Body as Commodity, 1964-2007." Labor 11, no. 1 (2014): 47-75.

Sedgwick, John. "Product Differentiation at the Movies: Hollywood 1946 to 1965." In An Economic History of Film, edited by John Sedgwick and Michael Pokorny, 187-217. London and New York: Routledge, 2005.

Sellors, C. Paul. "Collective Authorship in Film." The Journal of Aesthetics and Art Criticism 65, no. 3 (2007): 263-271.

Smith, Chris, and Alan McKinlay. "Creative Labour: Content, Contract, and Control." In Creative Labour: Working in the Creative Industries, edited by Alan McKinlay and Chris Smith.. Basingstoke and New York: Palgrave Macmillan, 2009.

Stollery, Martin. "Technicians of the Unknown Cinema: British Critical Discourse and the Analysis of Collaboration in Film Production." Film History: An International Journal 21, no. 4 (2009): 373-393.

Weinstein, Mark. "Profit-Sharing Contracts in Hollywood: Evolution and Analysis.” The Journal of Legal Studies 27, no. 1 (1998): 67-112.

\section{Newspapers}

"By Post from Mr. Capra,” New York Times, April 2, 1939.

"Memoirs of Thomas H. Ince," Exhibitors Herald, December 20, 1924.

"Putting the Move in the Movies," The Saturday Evening Post, May 13, 1916.

\section{Weekly Trade Papers}

“To Picture Yosemite,” The Nickelodeon, vol. 2, no. 1, July 1909, 31.

“St. George and the Dragon,” Moving Picture World, June 8, 1912, 933.

\section{Archival Sources}

Hollywood Film Industry Project, Oral History Collection, Columbia University: James Cagney, George Cukor, Myrna Loy, and Irving Rapper interviews.

Louis B. Mayer Foundation of Oral History, AFI Film Institute, Los Angeles: Nunnally Johnson interview.

Popular Arts Project in the Oral History Collection, Columbia University, New York: Mervyn Leroy and William Wyler interviews.

Special Collections, The Margaret Herrick Library, Beverly Hills: Rudy Behlmer, Gladys Hall, Hal Wallis, and William Wyler collections. 